\title{
LIVRO UTÓPICO E IMAGINAÇÃO MORAL
}

\author{
Eduardo Ferraz Felippe
}

O livro como centro de um projeto artístico está presente desde os primórdios da escrita de Ricardo Piglia. Os motivos mais óbvios dessa afirmativa provêm do percurso similar entre o escritor e o editor de livros, o que fez desde que editou séries de ficção policial. Percebo, além disso, a presença de recursos variados, voltados a desestabilizar as definições esperadas de livro, pelo menos desde 1975 com a publicação de Nome falso. Porém esse tema permaneceu submerso, sem muita relevância em sua fortuna crítica. Nova luz foi lançada aos seus escritos a partir do ano de 2015 com a publicação de dois volumes de Los diarios de Emilio Renzi. A edição desses cadernos, escritos por mais de 53 anos, foi um projeto editorial acolhido por grande parte da imprensa argentina e mundial como um empreendimento a sugerir nova visada em todo seu percurso artístico. Levar ao estranhamento uma obra desse porte, como os diários fizeram, somente foi possível pelo fato de que ela possuía, desde o início, brechas, rastros e pontos cegos. Não se trata de uma discussão sobre autoria, tema forte e já explorado por outros críticos, mas de entender como o livro surge feito um nó conceitual em sua obra. Lida com o problema da autoria, mas a submete a questões diversas como a circulação, a edição, a montagem, o que muda a herança formal a que esse texto se remete. A partir desse lugar, percebo que há um deslocamento das questões postas cuja finalidade é destacar o lugar do livro como um organismo que se remete à obra, mas que a desestabiliza e possibilita outras conexões. O ensaio que o leitor tem em mãos não é voltado ao estudo de Los diarios de Emilio Renzi, mas à construção de uma questão especial, o livro, dentro de uma obra que 
se apropria de materializações diversas dos textos, dos comentários dele derivados e dos produtos gerados pela crítica, como o filme 327 cuadernos. Argumento que os diários tendem muito mais à tradição romanesca do que aos diários escritos e publicados nos últimos anos.

Além do texto dos diários, o projeto editorial, os comentários a ele associados e o hibridismo presente retomam alguns temas deixados em aberto e pouco acabados desde Nome falso publicado em 1975. O diário reitera a menção a uma "autobiografia futura" que nunca ganhou materialização final e que se situa em uma dimensão utópica da busca por um sentido da leitura e da vida, antecipadamente fadada ao desengano. Trata-se de perceber que a organização do livro, dentro da obra de Piglia, é um problema em si mesmo e que demanda um olhar minucioso e ainda não efetivado por sua fortuna crítica. A reunião dos diversos textos em uma única publicação é um trabalho de poiesis, assim como a composição isolada de suas mais variadas peças. Ao tratarmos do problema do livro na obra de Piglia, há uma tensão entre montagem e forma final; o que termina por endereçar a escritura para o futuro, para uma dimensão utópica irresoluta e indefinível de modo pleno. Continua a seguir, dessa maneira, um dos dísticos de sua obra: a permanência da dúvida, a criação como uma forma permanente de desconfiança ante o que foi escrito. Creio que o problema do livro permita uma mirada particular em relação à sua obra. Especialmente ao longo do processo de publicação de seus diários, com o qual já temos dois volumes de três na totalidade, a modelagem de sua figura como escritor veio associada aos temas de sua escrita: o livro, a leitura, a autoria. O livro-questão dispara dois temas centrais: a autoria e os protocolos de escrita. Ao mesmo tempo, um terceiro tema deles derivados, o modo como esses textos são lidos por seus leitores e críticos, ou seja, como são destinados a afetar protocolos de escrita ao instigarem leituras inventivas da obra em mãos. Piglia permite entender impasses da circulação de suas obras, ao sugerir que elas não somente "circulam", mas que o livro como organismo aposta na desconfiança pela forma final do livro como uma renovação do ato de ler. O leitor está em primeiro plano em sua estratégia de escrita, mesmo que tenhamos clareza de que ele não leva essa opção até as últimas consequências como muitas obras de artes plásticas contemporâneas o fazem.

O nome como problema, em Piglia, diferencia-se de perspectivas esperadas tanto da escrita de si quanto da biografia ou da autobiografia. A reincidência de Emilio Renzi em sua obra investe de sentido novo os 
impasses da elaboração do livro como uma vertente forte em toda a ficção e nos textos críticos. Para aqueles já familiarizados com seus textos, o primeiro livro foi Invasão, mas somente a partir de Nome falso o tema ganhou destaque. Não sei se a alcunha de romance cabe para essa peça, nem mesmo a de ensaio. Tratado como uma "Homenagem a Roberto Arlt", Nome falso à primeira vista pode ser entendido como uma crítica às fronteiras entre os gêneros. Porém, a forma livro, indefinível no caso de Nome falso, está mais aberta ao comentário do que qualquer outra. O narrador da história visa a uma tarefa nada simples, editar um relato inédito de Arlt. Como comenta nas primeiras linhas do livro, com um tom de abertura de ficção policial

\begin{abstract}
O que estou escrevendo é um informe, ou melhor, um resumo: está em jogo a autoria de um texto de Roberto Arlt, de modo que vou tentar ser organizado e objetivo. Fui eu quem descobriu o único relato de Arlt, que continuou inédito depois de sua morte. O texto chama-se Luba. Arlt escreve-o aproximadamente entre 25 de março e 6 de abril de 1942. Ou seja, pouco antes de morrer. O texto foi escrito a mão, num caderno escolar, com letra apertada ocupando as margens. Luba é a peça mais importante numa coleção de inéditos de Roberto Arlt que comecei a compilar no início de 1972. Completavam-se trinta anos de sua morte, e fui encarregado de preparar uma edição comemorativa... (PIGLIA, 2002, p. 9).
\end{abstract}

Esse "informe", "resumo" ou "divulgação" rompe com as noções esperadas do livro pela articulação entre trama e montagem gráfica da peça. A estrutura narrativa do texto baseia-se no relatório da busca desse relato, as dificuldades para conseguir o manuscrito, além de tratar de uma apreciação crítica dos textos de Arlt e sua presença na tradição literária argentina. Narra também os encontros e desencontros para conseguir $L u b a$, o texto inédito, assim como o encontro com Kostia, poeta fracassado que conheceu Roberto Arlt. A intencionalidade é mais abrangente e específica, porém de validade ampla: dar nova leitura aos textos de Roberto Arlt. Utilizando mecanismos da ficção policial, Piglia constrói um livro no qual a apreciação crítica da obra de Arlt ganha outra ênfase e perspectiva, especialmente por o livro carregar consigo um apêndice com o manuscrito fruto da investigação. Seu papel é o de editor que visa entender as falsificações e as condições de emergência da obra de Arlt. O apêndice apresenta uma ambivalência indissolúvel: a recompensa pela investigação do crime é a pista que nos remete para fora do livro. Piglia transforma o apêndice em parte excluída da trama narrativa da investigação e, ao expô-lo como um texto de Arlt, passa a existir um desequilíbrio da 
obra do autor de Siete locos, assim como da própria obra de Piglia. O que está em jogo aqui é como a leitura demanda um posicionamento, um lugar, e como essa opção desestabiliza a noção de que um texto carrega consigo um nome próprio ou qualquer substância. O "Nome falso" deve ser entendido a partir do apêndice do livro: ele pode ser o de Piglia, caso seja lido a partir de Arlt; pode ser o de Arlt, caso lido a partir de Piglia; pode ser o de Piglia e Arlt, caso lido a partir de Renzi. Nenhuma fórmula dá a exata medida daquilo que se procura como a autoria final do texto. As notas de rodapé são tomadas enquanto instrumento de veracidade, porém nenhuma fornece a exata medida do verismo da trama.

A relação entre Kostia e Arlt parece ser uma construção inversa, como ângulos opostos pelo vértice, da relação entre Kafka e Max Brod. De todos os livros de Piglia esse é o mais inclassificável. Ao construir uma trama que enfatiza o papel do crítico como detetive, e mostrar o achado do crime, o apêndice, gera ressonâncias múltiplas para além da história contada e da obra de ambos. Relembra que um livro e uma obra podem ser feitos de falsificações, plágios, pequenas corrupções, esquecimentos e apagamentos voluntários que não podem ser solucionados de modo pleno. O livro é pensado como forma final inacabada na qual a mudança de cada parte isolada desestabiliza todo o conjunto e o deturpa. O narrador é o autor efetivo que dá a assinatura ao texto e exerce o papel de editor que encontrou um caderno de anotações dado por um aposentado afável.

Piglia percebeu algo. Quando falamos como se fosse outro, nossa história se torna muito mais fidedigna. Tudo bem que até esse momento muitos outros ficcionistas tinham percebido o mesmo. Aquilo que parece singularizar Piglia, entretanto, foi ter criado para si uma voz outra nos procedimentos em que todos os outros apostam na voz autoral como medida do encontro fidedigno. A introdução do autor suposto, Renzi, causa esse impacto para o autor efetivo em sua obra. Em seus ensaios, opta pela narrativa contada por um terceiro, Renzi, como forma de melhor sustentar seus anseios ou miradas críticas. Em seus diários, não se encontra o apego ao nome do autor como meio de alcançar a fidedigna representação dos eventos de uma vida. O caso mais recente e sintomático de toda a sua obra é Los diarios de Emilio Renzi - Años de formación (2015) e Los años felices (2016). Piglia, hoje com 76 anos, escreve rápido, devido à doença que avança a passos largos em direção a si limitando a voz do outro consigo, o seu sempre presente Renzi. Doença que o força a acelerar o processo de publicação/edição dos diários e que dá uma nota toda 
particular ao tema da poiesis livresca em sua obra. Diferente do tom do ensaio de Roberto Bolaño em seu Literatura + enfermedad = enfermedad não se encontra um desejo tão vigoroso pela vida externa ao texto; em Piglia essa relação melancólica com o texto é aguçada pela tensão entre a montagem e a reedição permanente das obras. Já havia testado a formadiário, porém com o intuito de propor outros caminhos para a análise crítico-ensaística. Entendo que a agressividade da doença o tenha levado a publicar de modo veloz e econômico seus diários, porém esse projeto de livro híbrido que negaria todos os livros anteriores vem sendo verbalizado por Piglia desde o início de suas publicações. Esse diário era o projeto inicial, a fonte e impasse de toda a sua escrita. Uma espécie de sombra, um mito. Todos os seus livros, a sua vida, estariam subordinados ao diário, e ele seria a condição para a leitura da obra.

Perguntado sobre o lugar do diário em sua escrita, Piglia (2014, p. 87) enfatiza em entrevista de meados dos anos oitenta

La relación ha ido cambiando y ahora es un poco el laboratorio de la ficción. Siempre digo que voy a publicar dos o tres novelas más para hacer posible la edición de este diario que se ha convertido en el centro de mi escritura. La forma del diario me gusta mucho, la variedad de géneros que se entreveían, los distintos registros. El diario es el híbrido por excelencia, es una forma muy seductora: combina relatos, ideas, notas de lectura, polémicas, conversaciones, citas, diatribas, restos de la verdad. Mezcla política, historias, viajes, pasiones, cuentas, promesas, fracasos. Me sorprendo cada vez que vuelvo a comprobar que todo se puede escribir, que todo se puede convertir en literatura y ficción. ${ }^{1}$

O diário como "laboratório da ficção" é um mito desde o início de seu percurso como escritor. Esse livro-diário não é um adereço que comenta outros investimentos poéticos, como no caso mais comum da escrita de diários, mas trata-se de condição de nascimento da escrita. $\mathrm{O}$ diário guarda uma ambivalência: potencializa a escrita, mas é também sua sombra e sua ameaça. Não se encontra o cotidiano, nem mesmo a busca por narrar uma forma coesa do "eu" que receba uma mirada ao fim da vida capaz de dotar de sentido todo o seu percurso terreno. Pelo contrário,

1 "A relação foi se transformando e agora ela é um pouco o laboratório da ficção. Sempre digo que vou publicar dois ou três romances a mais para tornar possível a edição desse diário que se converteu no centro de minha escrita. Gosto muito da forma do diário, a variedade dos gêneros aparentes, os distintos registros. O diário é o híbrido por excelência, é uma forma muito sedutora: combina relatos, ideias, notas de leitura, polêmicas, conversas, citações, fofocas, restos da verdade. Mescla política, histórias, viagens, paixões, promessas, fracassos. Surpreendo-me a cada vez que retorno a comprovar que tudo se pode escrever, tudo pode se converter em literatura e ficção." Todas as traduções deste artigo são nossas. 
nasce como uma forma contrária aos modos esperados de um diário "No tengo interés en registrar aquí mi vida cotidiana, mis actividades y las clases a las que asisto" (PIGLIA, 2015, p. 71). ${ }^{2}$ Trata-se de um diário heterogêneo, um livro composto por ensaios, anotações fragmentadas típicas de um diário, pouco dado a encontros memorialísticos. A partir daqui, uma interrogação imediatamente se impõe: que tipologia temos em mãos? Ou melhor, e mais adequado: a que linhagem Ricardo Piglia se direciona quando submete seu escrito ao título de "diário"?

Mais do que simplesmente expor suas ideias e reiterar tudo o que já foi dito a seu respeito, creio que trabalho aqui com um tema específico em sua obra, pondo em primeiro plano o livro. À primeira vista, tudo nos leva a crer que se trata de um diário comum, baseado em uma memória individual. Há recordações do avô italiano e a migração para a Argentina, lembranças da mãe e do cotidiano familiar, os casos amorosos do jovem Renzi, os encontros literários com Borges e Ezequiel Martínez Estrada, os amigos e suas bebedeiras em bares pela cidade de Buenos Aires. Essa indução, a conceber o diário como a tipologia textual acabada e final em Los diarios de Emilio Renzi é parte da estratégia de edição dos diários, assim como do jogo entre autor suposto e autor efetivo. Piglia manteve atenção à circulação e edição de livros, inclusive ao tratar da forma diário em "Notas sobre Macedonio en un diario" escrito para uma edição crítica do Museo de la novela de la eterna de Macedonio Fernandez, na Espanha, e depois publicado novamente em Formas breves; assim como "Notas en un diario", escrito em 1987, depois publicado em Antología personal (2014). O diário como montagem é, ao longo de todo o Los diarios de Emilio Renzi, talvez sua característica mais distinta. Como era de se esperar, um diário, escrito ao longo de 53 anos, deveria, pelo menos, mostrar algum grau de transitoriedade individual ou, então, certas dúvidas irresolutas, tensões mal resolvidas, inquietudes insaciadas. Um diário mostraria certa heterogeneidade na apresentação do "eu". Mesmo com a ambiciosa intenção de lidar com "la verdadera historia de mi vida", muitos eus poderiam ser apreendidos diante da pluralidade de um diário.

Nada disso se percebe aqui com a formação de Renzi. Pelo contrário, há uma preocupação forçosa e explícita por investir em certa homogeneidade do eu. "Por eso yo estoy transcribiendo mis diarios, porque quiero que sepan que hoy, a los setenta y tres años, sigo pensando lo mismo, criticando

2 "Não tenho interesse em registrar aqui minha vida cotidiana, minhas atividades e as classes que assisto." 
las mismas cosas que cuando tenía veinte años."3 Há uma mesmice que atravessa todo o escrito e se sedimenta na permanente intenção de valorar como unívoca a intencionalidade artística dos primeiros anos de Renzi. A viagem por sua vida nos anos de 1957 a 1967, no primeiro volume, e depois até 1975, no segundo volume, reforça um eu pouco dado a mudanças, especialmente quando trata de suas opções e gostos literários.

No hay evolución, nos movemos apenas, fijos a nuestras viejas pasiones inconfesables, la única virtud, creo, es persistir sin cambiarlas, seguir fiel a los viejos libros, las antiguas lecturas. Mis viejos amigos, en cambio, a medida que envejecen aspiran a ser lo que odiaban, todo lo que detestan ahora admiran, ya que no pudimos cambiar nada piensan, cambiemos de parecer, bibliotecas enteras enterradas, en el patio, quemadas en el incinerador, es difícil desprenderse de los libros, pero ¿y el modo de leer? Siguen igual, lectores dogmáticos, literales, dicen ahora cosas distintas con la misma sabiduría engolada de los viejos tiempos. Vivimos en el error de pensar que nuestros viejos amigos están con nosotros. ¡Imposible! Hemos leído los mismos libros y amados las mismas mujeres - por ejemplo Junior- y conservamos algunas cartas que no fuimos ni somos capaces de enviar o de quemar en la hoguera del tiempo y de eso trataría entonces mi autobiografía, si alguna vez me decidiera yo también a escribir una... (PIGLIA, 2015, p. 28). ${ }^{4}$

Piglia ainda não escreveu sua autobiografia futura. Creio que ela seja mais uma daquelas anedotas, uma espécie de sombras por trás de todas as suas declarações. Essa "autobiografia futura", como por diversas vezes comentou, é o livro em sua dimensão utópica, um "não-lugar" que motiva a escrita, o comentário, a vida. Um não-lugar que ataca os realismos e nossa forma de enxergar a escrita como uma resposta voluntária e imediata às demandas de publicação. Talvez essa "autobiografia futura" nunca escrita seja o elo que una toda a obra de Piglia, o anseio que se manifesta

3 "Por isso estou transcrevendo meus diários, porque quero que saibam que hoje, aos setenta e três anos, continuo pensando o mesmo, criticando as mesmas coisas que quando tinha vinte anos."

4 "Não há evolução, nos movemos apenas, fixos a nossas paixões inconfessáveis, a única virtude, creio, é persistir sem mudá-las, seguir fiel aos velhos livros, às antigas leituras. Meus velhos amigos, ao contrário, à medida que envelhecem aspiram a ser o que odiavam, tudo o que detestavam agora admiram, já que não podemos modificar nada, pensam, mudemos de aparência, bibliotecas inteiras enterradas, no pátio, queimadas no incinerador, é difícil desprender-se dos livros, mas e do modo de ler? Seguem iguais, leitores dogmáticos, literais, dizem agora coisas distintas com a mesma sabedoria afetada dos velhos tempos. Vivemos o erro de pensar que nossos velhos amigos estão conosco. Impossível. Temos lido os mesmos livros e amado as mesmas mulheres - por exemplo Júnior - e conservamos algumas cartas que não fomos nem somos capazes de enviar ou de queimar na fogueira do tempo e disso trataria, então, minha autobiografia, se alguma vez me decidisse a escrever uma..."

Remate de Males, Campinas-SP, v. 37, n. 1, pp. 175-199, jan./jun. 2017 
em imagens diversas em sua prosa de ficção, como Respiração artificial, La ciudad ausente e Blanco noturno, mas também em sua coletânea de ensaios e textos críticos como Antología personal. A "autobiografa futura" é escrita como variações em torno do mesmo tema, circulações em torno do mesmo ponto, a continuidade na mudança, os restos que permanecem ao se perceberem os cadernos alinhavados ao longo de toda uma vida. Essa passagem está presente em seu "Os livros de minha vida" (2015), escrito quando Piglia ganhou o prêmio Formentor e que foi colocado como o ensaio de abertura de Los diarios de Emilio Renzi com o nome de "En el umbral". A repetição e a montagem dos textos estão presentes nessa sua última empreitada, como uma espécie de mania capaz de significar protocolos de escrita e de leitura. Quando perguntado sobre a utilização de materiais pouco comuns e estranhos aos romances, Piglia (2014, p. 188) foi enfático em suas preferências e objetivos "A mi me interesan mucho los mitos de escritor, me parece que junto con los textos hay una aura, ciertas imágenes que actúan, en secreto, en los resquícios, entre las palabras [...]". Esse mito do escritor pode ser atacado tanto por temas de seus livros quanto pelos próprios materiais utilizados para a sua confecção “[...] leo muchísimo, yo diría más que novelas, leo diarios, biografias, cartas, correspondencias, ese tipo de material es un material que leo siempre por ese doble efecto de concentración que tiene, por un lado una vida convertida en destino, una vida leída, y a la vez la tensión entre el lenguaje y la experiencia..." (p. 189). ${ }^{6} \mathrm{O}$ duplo efeito concentrado desses materiais muda o funcionamento do livro e gera outros impasses de entendimento, como fez Piglia em Nome falso.

A bela citação de Franz Kafka, presente em seu escrito "Un pez en el hielo" de sua Antología personal, auxilia a entender o escrito

Aquel que no haya logrado alguna forma de acuerdo con la vida necesitará de una de sus manos para alejar de sí en lo posible la desesperación que le causa su destino -y no logrará gran cosa con ello-, pero con la otra mano podrá anotar lo que vea bajo aquellas ruinas, pues verá otras cosas, más cosas que los demás, ya que estará muerto en vida y será el sobreviviente real (PIGLIA, 2014, p. 47).7

\footnotetext{
5 "Interessa-me muito os mitos de escritor, me parece que há uma aura, certas imagens que atuam, em segredo, nos resquícios, entre as palavras...”

6 "Leio muitíssimo, diria mais do que romances, leio diários, biografias, cartas, correspondências, esse tipo de material que leio sempre por esse duplo efeito de concentração e que tem, por um lado, uma vida convertida em destino, uma vida lida, e a tensão entre linguagem e experiência...”

7 "Aquele que não alcançou alguma forma de acordo com a vida necessitará de uma de suas mãos para livrar-se o quanto possível do desespero que causa seu destino - e não Remate de Males, Campinas-SP, v. 37, n. 1, pp. 175-199, jan./jun. 2017
} 
Se há uma sobrevivência, se existe alguma ruína, ela se manifesta na fragilidade do eu unívoco em propor respostas para as dúvidas de sua memória. A sobrevivência é um investimento em imagens, utilizado no caso por Piglia a fim de garantir a permanência de determinados temas ao longo da obra. Para além de uma obsessão com determinado temário, tudo isso marca uma opção para tornar a montagem dos livros um procedimento de poiesis feito de abandono, perdas e insistências. A "forma de acuerdo con la vida" encontra em Piglia um modo de resolução particular, motivado pelo nascimento e pela reiteração da voz de Emilio Renzi. A figuração de uma outra voz permanente em seus escritos tanto nos propriamente ficcionais quanto em seus textos críticos. A utilização dessa voz outra dota de certa carga de ficcionalidade seus escritos ensaísticos, assim como permite que existam outras perspectivas analíticas em sua prosa de ficção.

Em uma nota do diário do ano de 1963, Renzi afirma enfaticamente que:

Me preocupa mi predisposición a hablar de mí como si estuviera escindido y fuera dos personas. Una voz íntima que monologa y divaga, una suerte de banda sonora que me acompaña todo el tiempo y que a veces se filtra en lo que leo o en lo que escribo aquí. Ayer pensé que tendría que tener dos cuadernos distintos. El A y el B. En el A estarían los sucesos, los acontecimientos, y en el B, los pensamientos secretos, la voz callada (PIGLIA, 2015, p. 135). ${ }^{8}$

Renzi trata de si como se fosse outro e mistura mais os papéis de Renzi e de Piglia.

En mi caso trabajo narrativamente la inversa: imagino, construyo hipótesis y versiones de un acontecimiento microscópico. Por ejemplo, encontré por azar en un libro de Inés la foto de uno de sus novios de la adolescencia. Un joven jugando al básquet en el club Peñarol. De inmediato convertí esa foto en un hecho del presente (se hizo presente, la foto que tenía siete años, porque yo la encontré ayer). Entonces el pasado de ella estuvo entre nosotros, no lejos de aquí, ya que la foto era una presencia ahora, como un tercero. Ésa es la lógica del delirio. Todo sucede en presente y algunos matan para salir de ese

fará muita coisa com ela -, mas com a outra mão poderá anotar o que vê abaixo daquelas ruínas, pois verá outras coisas, mais coisas que os demais, já que estará morto em vida e será o sobrevivente real."

8 "Preocupa-me a minha disposição de falar de mim mesmo como se estivesse dividido e fosse duas pessoas. Uma voz íntima que monologa e divaga, um tipo de ruído sonoro que me acompanha todo o tempo e que as vezes se infiltra no que leio ou no que escrevo aqui. Ontem pensei que deveria ter dois cadernos distintos. O A e o B. No A estariam os sucessos, os acontecimentos e, no B, os pensamentos secretos, a voz silenciosa."

Remate de Males, Campinas-SP, v. 37, n. 1, pp. 175-199, jan./jun. 2017 
tiempo absoluto y recuperar una temporalidad normalizada, el crimen es una consecuencia lógica de la pesadilla del presente, del peso de la pasión. Ése es el tiempo de la tragedia, no es el tiempo de la narración. Lo que se busca es que ese rasgo del pasado vuelva atrás, que la foto pierda su inmediatez absoluta y se construya en relato en el que tenga un lugar mínimo en una sucesión múltiple de los hechos vividos... (PIGLIA, 2015, p. 217). ${ }^{9}$

Apresentada como uma mania, a opção de Piglia revela a clareza de um projeto literário intimamente associado à percepção de um cenário de escrita argentino, latino-americano e mundial. Assim como em Gordon Pym, de Poe, trata-se de buscar a clareza dos gestos de inserção da narrativa. $\mathrm{O}$ nome do autor efetivo está ligado às formas ficcionais; porém, apresentado dentro da linhagem do diário, deveria supor formas não ficcionais e críveis. Sua credibilidade deveria estar atestada pela menção ao nome de amigos, intelectuais do meio argentino, escritores vivos e outros já falecidos. Ao indicar que os diários são de Emilio Renzi, e não de Ricardo Piglia, o autor propõe um deslocamento. Seu gesto essencial consiste em um processo de singularização, anunciando que as aventuras foram vividas por alguém chamado Renzi, depois contadas por um narrador, que por vezes corresponde a Renzi, por vezes, a Piglia. A garantia da autoria surge não exatamente pela voz do narrador, mas pela correlação estabelecida entre os diários como um livro conclusivo, e já não mais "laboratório da ficção", dessa obra A narrativa gera por si mesma uma imagem de narrador que o autor suposto, Renzi, se esforça por inculcar no leitor, convencendo-o de que se trata dele. E não se trata apenas de um narrador suposto, mas de um autor suposto para toda a obra que ganha legitimidade pela articulação entre o livro na forma diário e todos os outros livros na forma de prosa de ficção, contos e ensaios nos quais Renzi é o personagem principal.

\footnotetext{
9 "No meu caso, trabalho narrativamente ao inverso: imagino, construo hipóteses e versões de um acontecimento microscópico. Por exemplo, encontrei por acaso, em um livro de Inês, a foto de um de seus noivos da adolescência. Um jovem jogando basquete no clube Peñarol. Imediatamente converti essa foto em um fato do presente (se fez presente, a foto que tinha sete anos, porque a encontrei ontem). Então o passado dela estava entre nós, não longe daqui, já que a foto era uma presença agora, como um terceiro. Essa é a lógica do delírio. Tudo sucede no presente e alguns matam para sair desse tempo absoluto e recuperar uma temporalidade normalizada, o crime é uma consequência lógica do pesadelo do presente, do peso da paixão. Esse é o tempo da tragédia, não é o tempo da narração. O que se busca é que esse momento do passado volte atrás, que a foto perca a sua imediatez absoluta e que se construa no relato um lugar mínimo em uma sucessão múltipla de fatos vividos...”
}

Remate de Males, Campinas-SP, v. 37, n. 1, pp. 175-199, jan./jun. 2017 
Caso se tratasse de um diário ficcional, outra experiência de leitura estaria em jogo; o narrador carregaria a voz do autor suposto, mas não nos daria o grau de credibilidade dos eventos não ficcionais do cotidiano. Jakob von Gunten, de Robert Walser, por exemplo, alega ser um diário mantido por Jakob em sua permanência no Instituto, mas não deixa dúvidas de que se trata de uma ficção. Contém reflexões sobre o tipo de formação ali recebida, feitas por meio de um personagem bastante rarefeito e próximo da alegoria, o que torna difícil imaginá-lo como algum indivíduo. Robert Walser aposta em uma escrita que concatena uma lógica paradoxal convincente com uma lúcida organização sintática e justaposições causais do elevado e do banal que deixaram marcas em Kafka, especialmente em $\mathrm{O}$ castelo. $\mathrm{O}$ cinismo de Jakob com relação à civilização sugere um tipo pequeno burguês, mas que ainda assim não encontra um imediato paralelo na época. Narrar a experiência de Renzi não corresponde a buscar as coincidências entre Piglia e Renzi como forma de encontrar uma chave de leitura para toda a obra, mas de compreender o modo como o inverossímil do autor suposto abre um novo caminho para a destinação das ficções de Piglia, somente pacificado em um não-lugar do livro afirmado em sua obra. Essa abertura é dada pela articulação entre narrador, autor suposto e autor efetivo, e gera a destinação de seu escrito ao romanesco. Nunca a significação definitiva da obra, mas sua abertura às significações possíveis. Nunca um fechamento de sentido a seus escritos, mas sempre um convite ao comentário. Ele lida assim com a dissolução da forma-diário, assim como sempre lidou com a dissolução da forma-romance.

A citação mais precisa está explícita em Los años felices, em um já distante 1969

Tampoco me gustan los estilos afectados que circulan en la narrativa de mi generación: todos escriben con la voz de otro (sobre todo la de Borges, Onetti y Cortázar); por mi lado, a pesar de todo, una voz propia que no será necesariamente la mía, es decir, la que uso en la vida. Escribir con la sinceridad de un sujeto al que no conozco y que sólo aparece -o se asoma- cuando escribo (PIGLIA, 2016, p. 43). ${ }^{10}$

10 "Não gosto dos estilos afetados que circulam na narrativa de minha geração: todos escrevem com a voz de outro (sobretudo a de Borges, Onetti e Cortázar); quanto a mim, apesar de tudo, uma voz própria que não será necessariamente a minha, quero dizer, a que uso em minha vida. Escrever com a sinceridade de um sujeito a quem não conheço e que somente aparece -ou surge- quando escrevo." 
Talvez a citação que melhor se adeque às questões livro e autoria esteja já presente no primeiro diário de Piglia (2015, p. 189) seja: "He entrado en la literatura cuando he podido sustituir el 'él' por el 'yo', Kafka. En mi caso podría decir: he entrado en mi autobiografia cuando he podido vivir en tercera persona". "Já na composição de A Invasão existe uma correlação estreita entre a composição de personagens, o modo de entender o livro e a seleção de suas leituras. Mais uma vez, o diário Años de formación auxilia a entender o percurso de Piglia, assim como o modo de fundar sua tradição de leitura. O embaralhamento de leituras, de opções de vozes, e do nascimento do livro está clara em citação presente nesse diário, em anotação de agosto de 1965

Formalmente y en su estilo, La invasión no tiene nada que ver con Borges -o tiene que ver con o rechazo de su manera de entender la literatura-. En eso me diferencio de todos los escritores, que en general le copian hasta el modo de escupir. Nada tampoco con Cortázar, la otra plaga. Temáticamente la influencia es Arlt -demasiadas delaciones (PIGLIA, 2015, p. 198). ${ }^{12}$

Desse trecho atéa escrita de Nombre falso o percurso é curto. Contudo, a voz escolhida é a de outro, uma espécie de narrador-autor identificado plenamente com Arlt, ao ponto de criar um Arlt somente seu. A citação no início do livro mostra bem o intento: "Só se perde o que realmente não se teve". Atribuída no livro a Arlt, a frase, que é de Borges, consuma o intento último de citações falsas e atribuições errôneas. Atribuir a Arlt o que disse Borges é uma excelente forma de consumar um projeto de cruzamento de poéticas divergentes. Desse modo, cabe marcar bem a diferença: os diários não foram "transcritos" como por diversas vezes foram apresentados ao público em geral. E eles nem mesmo servem para acompanhar as transformações de um escritor ou a sua "formação". A pluralidade de linhagens contidas na forma-livro já é um indício. Os ensaios, os relatos ficcionais e os textos críticos, como "La moneda griega" (PIGLIA, 2015, pp. 273-281), são muito mais interessantes do que quando se aposta nas formas convencionais de um diário. Diferente do que se encontra nos diários de Pavese, que apostam na narrativa de uma vida

\footnotetext{
11 "Entrei na literatura quando pude substituir o 'ele' por 'eu', Kafka. No meu caso poderia dizer: entrei em minha autobiografia quando pude viver em terceira pessoa.”

12 "Formalmente e em seu estilo, $A$ invasão não tem nada a ver com Borges - ou tem a ver com a repulsa de sua maneira de entender a literatura -. Nisso me diferencio de todos os escritores, que o copiam até no modo de esculpir. Nem mesmo com Cortázar, outra praga. Tematicamente a influência é Arlt - muitas delações."
}

Remate de Males, Campinas-SP, v. 37, n. 1, pp. 175-199, jan./jun. 2017 
coesa marcadas por uma problemática central, a poesia, Piglia investe na pluralidade formal para nomear isso que se chama de vida. No caso desse autor, nada pode ser mais explícito do que suas diferenças, suas insuficiências, sua precariedade em apresentar um diário.

Sustento a hipótese de que Los diarios de Emilio Renzi remetem mais ao romance do que a outros diários. Uma aproximação possível com Robert Musil, que chamava suas anotações diárias de "cadernos" (Hefte) e que apenas tiveram sua publicação post mortem como diários (Tagebücher) devido à intervenção do editor. Nos diários de Musil, lidos por Piglia, há resenhas, partes de livros, esboços de ficção, notas de leitura, projetos de ensaios, que distorcem os modos esperados de um diário. Comparado a outro escritor de diários, como Paul Auster, não se percebe, em Piglia, tanta força da memória. No autor de Diário de inverno, a memória é quase onipresente e não se percebem recursos comuns aos atos de fingir de uma escrita ficcional. Ele elabora um diário com uma força de concentração distinta, especialmente por perceber-se elaborando uma obra final. Desse modo, Los diarios de Emilio Renzi não são uma preparação para uma outra obra, como um romance, eles já são essa obra. O diário de Pavese, por outro lado, segue uma cronologia, salta dias, e não meses, e não apresenta intervenções modeladoras em seus escritos, ao se apresentar de modo muito mais homogêneo do que o texto de Piglia. Los diarios de Emilio Renzi são uma forma de antidiário, um diário que não escreve a vida que passa, mas busca uma forma de vida de dimensão utópica, nunca alcançável de modo pleno. Los diarios de Emilio Renzi são muito mais interessantes quando lidos a partir de um problema, o do livro, do que estudados enquanto um texto que se alinha à linhagem da escrita dos diários de escritores. Sua busca por encontrar uma dicção própria tem no diário apenas mais um rastro, não o rastro, que nos permite uma mirada singular para o interior da obra e para fora dela. No caso de Piglia, os diários não são um adereço da obra, como em Pavese, ao lidar com a poesia. Los diarios de Emilio Renzi são parte intrínseca de sua automodelagem vocacionada ao espaço público; são um eixo de articulação da obra de Piglia que nele encontra uma proposição de sentido que ilumina, por ângulos diversos, todos os outros escritos. Os diários de Pavese, em seu Oficio de viver, são uma obra segunda, um discurso segundo frente à vida e poesia. Os dias contados linearmente têm em seu centro comentários acerca da elaboração de textos poéticos, como escreve em 6 de outubro de 1935: "Apesar de algumas das minhas poesias 
mais recentes serem convincentes, não tira a importância o fato de que as componho cada vez mais com indiferença e relutância"ı3 (PAVESE, 1974, p. 23) ou em outra citação de 26 de fevereiro de 1940 "Poesia e pintura. Não deve existir em uma poesia tempo empírico, bem como em um quadro não deve existir espaço empírico" (p. 169).14

Em Piglia, não há uma vida a ser narrada. A vida não está em seus 327 cadernos. Reconhecemos a vida quando lemos os cadernos; ela é mais uma narração, e poderia ser qualquer outra, contada após o contato com seus diários. Eles não são sua memória. Renzi não é Piglia, é uma voz outra. Pode ou não ser Piglia. O Piglia que buscamos é apenas porque percebemos a verossimilhança como efeito do texto. O livro dentro da linhagem do diário amplia a noção do que se entende por livro dentro da obra. A vida surge serva da ficção, assim como o Tlön de Borges. O livro que dita o mundo. O aproveitamento desse nó conceitual em sua obra, muito mais do que um tema, ocorreu como uma imagem literária central em La ciudad ausente em que há uma pólis joyciana na qual apenas o Finnegans Wake sobrevive diante da mortandade precoce das línguas. Sua continuidade legível e transparente reorganiza o mundo sem que as línguas sejam tomadas como um cogito onipotente, porém se sucedem como "um pássaro branco que muda de cor" já que os moradores da ilha "falam e compreendem instantaneamente a nova língua mas esquecem a anterior" (PIGLIA, 2002, p. 123). A imagem literária do livro como centralidade da escrita alimenta todo La ciudad ausente e serve de metáfora para a obra inteira. Demanda outros critérios de leitura, assim como realça a montagem da obra e o nascimento do livro como entidade autônoma, o que ataca qualquer ranço romântico das noções de autoria e originalidade ou qualquer valor efusivo destinado ao biográfico.

É justamente buscando a crítica ao mito do escritor que Piglia narra seu encontro com Ezequiel Martinez Estrada. Mais uma vez o tema da morte e da autoria aparece em suas afirmativas que lidam com o presente e o futuro da escrita e do livro.

Por pura decisión testamentaria había decidido que su libro se publicara en una fecha que dejaba en un sobre que debía ser abierto a los veinticinco años de su muerte. No antes ni después. La verdadera legibilidad es siempre póstuma. Escribimos para los muertos y también para las pesquisas. Porque ellos leen

13 "Che qualcuna delle ultime poesie sia convincente, non toglie importanza al fatto che le compongo con sempre maggiore indifferenza e riluttanza."

14 "Come del tempo, cosí dello spazio. Poesia e Pittura. Non deve esistere, in una poesia, tempo empirico cosí come in un quadro non deve esistere spazio empirico."

Remate de Males, Campinas-SP, v. 37, n. 1, pp. 175-199, jan./jun. 2017 
todo, registran todo. En el fondo escribimos para la inteligencia del Estado. ¿Cómo impedir que nos lean? Quería convertirse en inédito. En su Discurso a la Universidad iba a insinuar que pensaba publicar su libro con seudónimo, pero no con un seudónimo, con otro nombre que nadie pudiera, ni remotamente, asociar con el suyo. Nadie iba a conocer con qué nombre pensaba publicar su libro anónimo, pero eso iba a llamar la atención. ¿No sería mejor publicarlo como un libro inédito de un escritor conocido, atribuírselo a otro, dejar que lo lean como si fuera de otro? Le gustaría que cualquier libro que se publicara después de su muerte pudiera ser leído como su obra. (PIGLIA, 2015, p. 66).15

Não nos cabe concordar plenamente com esse trecho de Renzi. A “verdadera legibilidad” está disponível para os próximos e para os distantes, aos vivos e aos mortos. Talvez o que de melhor Piglia retire de sua leitura de Ezequiel Martinez Estrada seja a possiblidade de que suas palavras e as dúvidas ecoem no porvir. Construir a si como se fosse outro e deixar o destino da leitura embaralhar o futuro

Un libro perdido en el mar de los libros futuros. Una adivinanza lanzada a la historia. Una obra pensada para pasar, como quien dice, desapercibida. Para que alguien la encuentre por azar y entienda su mensaje. Ésa era su estrategia frente a la política de desconocimiento, aislamiento, amenaza y guerra que le había entablado la intelectualidad dominante. (PIGLIA, 2015, p. 66). ${ }^{16}$

Embaralhar esse futuro como se fosse outro autor, outra voz, outra dicção passa a ser um desafio escolhido por Piglia. Essa provocação lançada à história, essa obra a ser tomada como despercebida, era levar ao limite toda a castração legada por aqueles que buscaram silenciá-lo. A continuidade da passagem somente faz sentido caso se reconheça que Piglia também buscou para si caminho similar, sob a alcunha de Renzi (ou esse se desprendeu dele querendo significar outro?). Ao falar de si mesmo,

15 "Por pura decisão testamentária, decidiu que seu livro seria publicado vinte e cinco anos após a sua morte. Nem antes, nem depois. A verdadeira legibilidade é sempre póstuma. Escrevemos para os mortos e também para as pesquisas. Porque eles leem tudo, registram tudo. No fundo escrevemos para a inteligência do Estado. Como impedir que nos leiam? Queria converter-se em inédito. Em seu discurso na Universidade ia insinuar que pensava publicar seu livro com pseudônimo, porém não com um pseudônimo, com outro nome que ninguém poderia, nem remotamente, associar ao seu. Ninguém iria saber com que nome pensava em publicar seu livro anônimo, porém isso iria chamar atenção. Não seria melhor publicá-lo como um livro inédito de um escritor conhecido, atribuí-lo a outro, deixar que o leiam como se fosse outro? Gostaria que qualquer livro que se publicasse depois de sua morte pudesse ser lido como sua obra."

16 "Um livro perdido no mar de livros futuros. Um enigma lançado à história. Uma obra pensada para passar, como se diz, desapercebida. Para que alguém a encontre ao acaso e entenda sua mensagem. Essa era sua estratégia frente à política do desconhecimento, isolamento, ameaça e guerra que lhe havia legado a intelectualidade dominante"

Remate de Males, Campinas-SP, v. 37, n. 1, pp. 175-199, jan./jun. 2017 
Renzi se refere a Martínez Estrada como se sua escrita somente tivesse sentido caso fosse tomada em uma relação simétrica ao poeta argentino. "Donde todos se enriquecen y se cubren de honor, yo construyo un plan para aniquilarme." (PIGLIA, 2015, p. 66) ${ }^{17} \mathrm{O}$ apagamento do eu é buscado por Martínez Estrada como uma resposta às perseguições impostas pelo Estado que busca silenciar sua voz. Decisão semelhante àquela que havia tomado quando conseguiu ser agraciado por ter recebido prêmios pela publicação de suas obras poéticas. "Esa decisión es simétrica a la que había tomado en sus comienzos: cuando recibió los máximos honores y fue reconocido como el mayor poeta argentino y el más virtuoso de los maestros de la lengua, entonces dejó de escribir poesía." (p. 66)..$^{18}$ Se esta foi uma lição, pode-se dizer que foi bem aprendida por Piglia, ao criar Renzi: "La obra maestra voluntariamente desconocida cifrada y escondida entre los libros" (p. 66). ${ }^{19}$

Circularidade e repetição marcam essa escrita que carrega consigo uma dimensão utópica da verdade. A repetição como escolha de protocolo de escrita assim como opção fiável, ao leitor, na montagem da sua obra, especialmente aquela repetição destinada aos textos críticos. Tratadoagora sob a tutela da chamada forma-diário, o futuro e a montagem destacam-se no temário de toda a sua obra afetando especialmente o modo de pensar a constituição do livro, assim como surgiam em forma de temário em prosas de ficção anteriores Ou então, como presente em seu diário "Las sorpresas que yo mismo me tiendo. Inventar una causalidad, un destino hecho de encuentros azarosos, coincidencias, elegir el futuro, inventar los días que han de seguir esta tarde" (PIGLIA, 2015, p. 58). ${ }^{20}$ A dimensão utópica o estabelece como um abrigo, precário e dado a turbulências, mas no qual sempre podemos investir algum sentido. "Cuando quiero tranquilizarme me refugio en el futuro: dentro de diez años me voy a reír de todo esto.” (p. 59). ${ }^{21}$

17 "Onde todos se enriquecem e se cobrem de honra, eu construo um plano para aniquilarme."

18 "Essa decisão é simétrica à que havia tomado em seu começo: quando recebeu as máximas honras e foi reconhecido como o maior poeta argentino e o mais virtuoso dos mestres da língua, então deixou de escrever."

19 "A obra mestra voluntariamente desconhecida, cifrada e escondida entre os livros."

20 "As surpresas que eu mesmo me dou. Inventar uma causalidade, um destino feito de encontros casuais, coincidências, eleger o futuro, inventar os dias que seguirão a esta tarde."

21 "Quando quero tranquilizar-me, me refugio no futuro: dentro de dez anos vou rir de tudo isso." 
No que se refere ao projeto do livro como poiesis na obra de Piglia, outra referência central é Macedonio Fernandez e sua literatura como desafio ao futuro. "Uma das aspirações de Macedonio era converter-se em inédito”, dizia Piglia como uma estratégia que incorporou para si mesmo. "Apagar as marcas, ser lido como se lê a um desconhecido, sem prévio aviso". Piglia atribui a Macedonio a frase que incorpora em seu projeto intelectual; "Atribuir seu livro a outro: o plágio ao revés" (PIGLIA, 2014b, p. 23) foi como Piglia por diversas vezes reafirmou em seu livro Crítica y ficción ao remeter-se a Macedonio Fernandez. Um livro sem autor, uma atribuição falsa, o uso do pseudônimo: três modos diversos de embaralhar os sentidos esperados do que se entende por livro e consequentemente por autoria e obra como propriedade intelectual. Ao negar o presente, Piglia o concede à obra, e torna o presente a afirmação sem presença, o livro como uma presença que destaca um vazio, sempre em falta com relação à existência real. A dúvida pertence à certeza poética, assim como a impossibilidade de afirmar a obra pertence ao seu próprio espectro. Um livro sem destino final encontra sua destinação em um porvir. Longe estamos da tradições romântica. Piglia nega a existência de uma verdade final, mesmo que seja o autor, ao utilizar a verossimilhança como recurso para uma ficção.

O trato com o Renzi do diário ocorre pela unificação da voz do narrador com o personagem Emilio Renzi, por meio da utilização do discurso indireto livre. A supostamente crível intimidade do personagem, e narrador de experiência da vida, ou seja, do próprio Piglia, coincide com a natureza textual e o eixo de toda uma obra, com o nome Ricardo Piglia. Porém, o trato com Renzi como personagem de suas ficções históricas diverge frente ao trato com o Renzi de seu diário. O uso do discurso indireto livre, que representa a interpenetração da expressão subjetiva do personagem com a voz do narrador, tende a ocorrer mais quando se trata de suas ficções históricas. Em Los diarios de Emilio Renzi - Años de formación, a força emotiva do personagem Renzi se dá pela interseção da suposta cognoscibilidade com a aparente profundeza, inspirando no leitor uma sensação de intimidade, apesar de sua inexistência. O prazeroso sentido de familiaridade com o personagem se dá pela ficcionalização operada pela escrita ao dar-lhe o nome de Emilio Renzi. Porém, a inexistência no real ela nunca é plena, no caso desse diário. A dúvida permanece entre todos: o narrador e o leitor, visto que nunca está claro se estamos tratando de Renzi ou de Piglia. Nos ensaios, ou na forma híbrida 
diário, percebe-se a interpenetração entre o narrador e o personagem e, por outros momentos, sua mais profunda diferenciação. Por isso, para que a familiarização com o personagem ocorra há uma profunda sensação de incerteza, manifestada a princípio pelo nome Renzi. Ricardo Piglia segue dois caminhos demarcados ao explicitar o rigor da representação: primeiro, o investimento no mesmo personagem Renzi, ao longo da obra e, depois, a afirmação de que toda a sua obra parte de um núcleo comum, um único livro, manifestado por seus diários.

Assim como nos romances em primeira pessoa, a revelação da natureza da ficção ocorre, especialmente, por meio da utilização de técnicas para indicar a diferenciação entre o autor implícito e o narrador. Nesse caso, há um investimento na opacidade do personagem Renzi, que não é descrito de modo imediato ao longo de todo o relato e que, por diversas vezes, alterna sua voz com a do narrador, que ali pode ser Renzi, mas pode ser também Piglia; o que permite a articulação com a incerteza epistemológica, típica do modernismo. $\mathrm{O}$ esforço hermenêutico nesse caso nunca cessa. Tanto o personagem-narrador (Piglia ou Renzi) quanto o personagem que teria escrito o diário (Renzi) dão origem a uma afecção melancólica, incentivada pela tensão entre a insistente exibição da subjetividade do narrador e o objeto de seu desejo, o personagem, que, cada vez mais obscuro, se confunde com o narrador, o autor e o editor de livros. Como em frase insistentemente reafirmada por Piglia (2015, p. 338): "Las historias proliferan en mi familia, dijo Renzi. Se cuentan las mismas una y otra vez, y al contarlas y al repetirlas mejoran". ${ }^{22}$ Renzi gera a identificação por ser acabado e, ao mesmo tempo, incompleto; do mesmo modo não sabemos previamente se estamos lidando com Piglia ou Renzi, o que coloca o destino do livro em uma posição ambígua entre o cumprimento de uma promessa e a submissão ao destino. A promessa, os diários que concluiriam a obra de Piglia; o destino, a morte do autor que sofre de esclerose múltipla e não conseguirá editar seus diários.

Se a narrativa realista europeia propôs uma caracterização autossuficiente, o que diminui a nossa curiosidade por seus personagens, já o modernismo e o pós-modernismo nos aguçam essa mesma curiosidade ao investir na insuficiência do personagem. No caso de Renzi, não conseguimos resolver o enigma, descobrir o que não está dito, se ele é Piglia ou Renzi, o que termina por ser mesmo a parte mais interessante do

22 "As histórias proliferam em minha família, disse Renzi. Contam-se as mesmas uma e outra vez e, ao contá-las e repeti-las, melhoram." 
diário. Se o lermos colocando à parte a questão da dubiedade de quem será o narrador, ele lembra, vagamente, qualquer livro em que esteja em jogo o processo de formação de um personagem em sua luta com a forma para o desenvolvimento artístico. Nada muito diferente do que foi legado. Nada muito estranho aos Anos de aprendizagem de Wilheim Meister de Goethe. Muitos dos fatos narrados no diário trazem a marca de acontecimentos ocorridos com Piglia e do conhecimento de todos, como as primeiras publicações de seus textos, já nos idos de 1967.

Mas não se trata de uma biografia ou uma autobiografia em termos convencionais. Piglia, desde que sua obra passou a ter relevância e conhecimento no meio argentino, no início dos anos oitenta, dizia que pretendia escrever uma "autobiografia futura". Nunca a escreveu; a sua autobiografia ficou no terreno da utopia, em um sem lugar futuro que alimenta nossos anseios no presente. Como no Livro por vir, de Blanchot (2013), a obra apresenta um devir que lhe é próprio por meio do conflito entre a presença evidente e sua irrealidade. O diário é uma resposta a esses anseios, mas não é a execução desse intento. A representação que faz da consciência de seu personagem Renzi diverge sensivelmente daquela feita por biógrafos; qual tende a ser muito mais gramaticalmente estável do que nesse exercício ficcional levado a cabo por Piglia. A instabilidade da posição do sujeito é mais uma vez aguçada por esse acesso à vida mental do personagem enfatizado.

Os livros publicados sob o título Los diarios de Emilio Renzi, retomam e colocam novamente - e de modo adequado - o problema do livro na obra de Piglia, porém suscita tema correlato à questão do arquivo. Há uma fortuna crítica atenciosa que abordou o lugar do arquivo na produção do conhecimento. Tratam do arquivo como limite e possibilidade de construção de significado. Piglia a ela se refere de modo criativo e único. Arquivo aqui deve ser compreendido em sua obra de modo amplo, como suas cadernetas escritas ao longo de toda a sua vida, no mesmo tipo de caderno comprado em uma banca em Buenos Aires. Piglia gostava de contar uma anedota sobre seus cadernos; dizia que caso os cadernos deixassem de serem impressos e vendidos nas bancas abandonaria a escrita. Seu arquivo, então, é privado, mas sujeito aos impasses e regras de outro arquivo qualquer. Por isso, o arquivo é um excelente exemplo do impasse da narração em nossa época. Diferentemente da ficção policial clássica, em que o investigador busca pistas para reconstruir a narração ou de modo semelhante o fato de que, no arquivo todas as pistas estejam 
dadas e nos falte reconstruir algo corrompido como uma versão, aqui nomeada de diário.

Foi a partir de seu retorno para a Argentina que ele tomou seu arquivo, como gosto de chamar seus cadernos, como a condição para a escrita, agora sob a alcunha de Los diarios de Emilio Renzi. O arquivo é formado por 327 cadernos de capa negra, da marca Congreso, e demarca tanto a possiblidade do conhecimento quanto os limites para aquilo que pode ser dito. Como pondera o Foucault (2008) da Arqueologia do saber é a partir do interior das regras a que falamos e é por meio delas que são determinados os modos de aparição, as formas de existência e coexistência, a acumulação, a historicidade e a desaparição. Há alguns tropos do modelo do Arquivo na narrativa de Piglia, como a acumulação de cadernos, o depósito e o trânsito com seus textos por diversas partes do mundo. Há um caráter quase mítico quando Piglia se refere aos seus cadernos, ao seu arquivo, ao longo da vida, pelo menos desde Critica y ficción. Eles surgem para nós dotados, pela palavra de Piglia, de um poder arcano originário, difícil de expressar, mas que se sustenta na expressão mesma do arquivo, e não separado dele, o que o impossibilita de se tornar completamente discursivo. A figura da morte - do autor, do personagem - surge assim como a aparição do limite, o que dota de uma tonalidade sacra o gesto de editar os escritos e, a partir deles, reconhecer-se na palavra e no nascer do livro. O tom sacro dado aos diários encontra um contraponto, e não um inimigo, na ficção como discurso hegemônico manejado por Piglia, capaz de respaldar e dar uma entonação adequada ao que se apresenta enquanto vida, nos diários. Não se trata de nostalgia com relação a uma linguagem sacra, mas da percepção de que o tom ficcional valoriza a pluralidade de escolhas, e não uma narrativa única típica no sentido religioso.

A passagem dos 327 cadernos para o livro Los diarios de Emilio Renzi, auxilia a entender a relação entre conhecimento e escrita de um modo próprio. Enquanto depósito do conhecimento, seus cadernos eram a expressão do estabelecido, e poderiam ser chamados de a tentativa de narrar uma vida; transformados em diários, ganham a forma do livrodiário e questionam qualquer possibilidade de definição última do que seja vida. Por isso, a ideia de um arquivo (ou baú, no caso de Piglia) se baseia muito mais em uma contiguidade do que em uma continuidade; construído a partir da separação e da diferença, da seleção e da reunião, como as marcas de nascimento da escrita dos diários. Seu baú cheio de 
cadernos seguiu o princípio de organização cronológica, aguardando o agente exógeno para criar um cenário para o nascimento do diário por vir. Escrever Los diarios de Emilio Renzi não significa dar a conhecer uma vida, como nos diários de Pavese, mas reconhecer a vida como uma leitura de um personagem que poderia ser qualquer outro. Por isso, a questão aqui é o livro, e não o diário. "No hay nada más ridículo que la pretensión de registrar la propia vida. Uno se convierte automáticamente en un clown [...] hablar de mí es hablar de ese diario. Todo lo que soy está ahí pero no hay más que palabras." (PIGLIA, 2015, p. 125) ${ }^{23}$ A vida não é simplesmente a apresentação daquilo que está contido nos diários, por outro lado, ela se assemelha muito mais a um trabalho de edição e de reconhecimento. Uma forma de autorreflexão a partir dos diários que coloca em jogo um percurso autoconsciente da escolha da pluralidade de "eus" possíveis e a elaboração de uma apresentação pública. O jogo com a memória existe; colocamse em evidência fatos mínimos, apresentam-se em primeiro plano alguns detalhes, apagam-se páginas inteiras de dias de trabalho e estudo. Esse ato de edição é voluntarioso. Não se trata de descobrir quem se é ao olhar para trás em busca de algo similar ao tempo perdido; pelo contrário, a edição aguça o desejo de querer ser o que não se é, mesmo quando narrado sob o nome de um alter ego que sempre reforça os laços com o mesmo nome do autor. Trata-se de um vir a ser como marca do diário, e não uma autobiografia, no sentido de uma narração de um indivíduo coeso em suas peripécias ao longo da vida.

Não há um modo autêntico de apresentar a vida de Ricardo Piglia, mesmo sob a alcunha de Renzi. Cabe lembrar que a autenticidade e a sinceridade podem ser compreendidas como formas diversas, porém relacionáveis, na afirmação do eu no Ocidente. Sinceridadee autenticidade são valores fundamentais em uma sociedade de indivíduos, em que as pessoas não se definem por seu nascimento e são marcadas pela igualdade jurídica de agentes sociais. A formação da subjetividade carregou consigo um pano de fundo moral relacionado aos principais horizontes que orientaram a construção do sujeito nas sociedades contemporâneas, atrelado à relação dinâmica entre indivíduo e sociedade. Como no instigante estudo de Lionel Trilling (1972), a sinceridade, o cálculo do grau de congruência entre declaração e sentimento, sugere que ser verdadeiro

23 "Não há nada mais ridículo do que querer registrar a própria vida. Qualquer um se converte automaticamente em um palhaço [...] falar de mim é falar desse diário. Tudo o que sou está aí, porém não há mais do que palavras."

Remate de Males, Campinas-SP, v. 37, n. 1, pp. 175-199, jan./jun. 2017 
não é um fim, mas um meio. O eu carrega consigo um objetivo moral que supõe uma finalidade pública e a correlata insinuação com relação à estima e à reputação. Sermos sinceros é uma exigência social, que cumprimos com eficácia ao assegurarmos nossa sinceridade, de fato, por meio de ações direcionadas à conformação de uma modelagem ao público.

Piglia foi um leitor criterioso da obra de Lionel Trilling, o que se percebe pelas citações de admiração e visadas críticas, especialmente de The Opposing Self, presente em nos ensaios e no diário. Ao escrever seus diários, coloca uma nota particular em sua leitura: é sincero com os anseios da sociedade ao interpretar o papel de si mesmo por meio de outro personagem que narra seu próprio percurso. Renzi é o outro de Piglia como um cálculo para contar uma trajetória individual e um percurso de leitura, como se não tivesse ocorrido nenhuma interferência capaz de gerar um ruído em sua composição enquanto escritor. Os diários, ao funcionarem como os anos de formação e os anos felizes de Renzi, narram um sincero escritor que mantém as mesmas intenções de jovem e o mesmo cabedal de leituras, desde que começou a escrever. Esse é um intento já afirmado na apresentação e na divulgação do livro e reiterado nos ensaios. Ao mesmo tempo serve à intencionalidade de manter coesa a identidade do autor, que desde os primeiros anos lê Borges e Arlt e fala fluentemente inglês, além de ser um distinto conhecedor de ficção policial e possuir uma participação ativa nas rodas literárias de Buenos Aires. Uma performance voltada a apresentar uma coesão onde há pluralidade do "eu".

Uma distinção de Piglia é entender que esse ato de conformação da sua modelagem não ocorre apenas por meio da escrita, mas engloba o livro como poiesis e é parte indissociável da formulação de seu perfil como escritor. O que aproxima Los diarios de uma empreitada romanesca, como se Piglia, a partir da leitura de Lionel Trilling (1950, p. 255), especialmente em seu "Art and Value", visasse responder à pergunta sobre se o romance ainda é uma forma viva. Incorpora, da leitura que Trilling faz de Henry James, que o valor do romance é sua flexibilidade e variedade, e tenta executá-lo em Los diarios de Emilio Renzi. Tenta assim transformar seu livro utópico, o diário, na encarnação temática da variedade e flexibilidade buscada na tradição romanesca. Alinha-se à leitura feita por Trilling da obra de Georg Orwell, 1984. Ao escrever a apresentação da prosa de ficção ao público norte-americano, Trilling considera que "a revolução idealista se transformou em polícia de Estado", o que teria levado à imagem de um futuro ameaçador. Assim como Trilling consegue ler T. S. Eliot do ponto 
de vista de um moralista, entende "moralista" em um sentido amplo do termo. O que interessa é o "realismo moral" retirado da leitura que Piglia faz de Trilling. Opto por alinhar Piglia ao anseio de Trilling (1950, p. 222), de que o "realismo moral" é o produto do livre jogo da "imaginação moral".

Esse comentário auxilia a entender a relação entre história e imaginação moral em Piglia. Apesar de possuir como referente a recente história argentina, os diários, que são de Renzi, joga com necessidades e possiblidades do leitor. Rompe com o usual sentido de necessidade entre mundo, obra e artista. Piglia escreve seus diários preocupado em lidar com a verdade, e não com a realidade, do passado argentino, o que, apresentado sob a escrita de Emilio Renzi, atua hipoteticamente construindo uma imagem peculiar de seu presente. $O$ passado surge em movimentos súbitos da lembrança, o presente surge em fragmentos e o futuro permanece em aberto. Contrário a muitos diários contemporâneos realistas ou naturalistas, Los diarios de Emilio Ranzi apostam em anacronismo, múltiplas vozes, narrador que é Piglia ou Renzi; assim recusa-se a se tornar uma fonte simples de entretenimento nem um “documento" de época. Recusa-se, também, a se tornar o lugar da representatividade cultural latino-americana, como no boom literário, e também um lugar em que os anseios de uma esquerda pudesse encontrar mais um reduto. Constrói assim uma imagem verdadeira sustentada pela prosa na complexidade que dedica à forma-diário. As dissociações, aproximações e distanciamentos entre autor efetivo, autor suposto e narrador são o modo melancólico com que Piglia lida com a dificuldade, talvez a impossibilidade, de definir o que seja o próprio "eu". Não há a elaboração nem suporte onde esse "eu" pudesse ser encontrado, não há uma formatação comum do diário em que um "eu" pudesse por fim definir Piglia; ao falar de Piglia, a partir de Renzi, embaralha as possibilidades e sugere o próprio apagamento de qualquer possível definição de quem seja Piglia. Como se o nome fortuito de Michel dentro do Em busca do tempo perdido de Proust pudesse também ser reconhecido como uma precedência possível, especialmente por ter sido posto como epígrafe do escrito de Renzi. A vida de Piglia como uma leitura de seus cadernos, de seu livro utópico transformado em Los diarios. Dizer desde os primeiros anos seu diário guardaria o que de melhor houvesse em sua escrita corresponderia a uma busca por modelar e encontrar um significado, por meio de uma imputação de sentido, ao seu passado. Assim, o transforma em um vir a ser como uma formação artística e seu livro como uma possibilidade dessa materialização. 


\section{REFERÊNCIAS BIBLIOGRÁFICAS}

BLANCHOT, Maurice. O livro por vir. Trad. Leyla Perrone-Moisés. $2^{\underline{a}}$ ed. São Paulo: Martins Fontes, 2013.

BOLAÑO, Roberto. Literatura + enfermedad = enfermedad (Ensayo). 1999. (Mimeo.)

BORGES, Jorge Luis. Tlön, uqbar, orbis tertius. In: Ficções. Trad. Davi Arrigucci Jr. Companhia das Letras: 2007, pp. 13-34.

FERNÁNDEZ, Macedonio. Museo de la novela de la eterna. Edición critica. Paris / Madrid / Rio de Janeiro / São Paulo: ALLCA XX, 1996.

FOSTER, Hal. An Archival Impulse. October, v. 110, 2004, pp. 3-22.

FOUCAULT, Michel. Arqueologia do saber. Trad. Luiz Felipe Baeta Neves. $7^{\underline{a}}$ ed. Rio de Janeiro: Forense Universitária, 2008.

LEDERACH, John Paul. The Moral Imagination. The Art and Soul of Building Peace. Oxford, 2005 .

PAVESE, Cesare. Il mestiere di vivere: diario (1935-1950). Torino: Einaudi, 1974.

PIGLIA, Ricardo. La ciudad ausente. Buenos Aires: Debolsillo, 1992.

PIGLIA, Ricardo. Nome falso: homenagem a Roberto Arlt. Trad. Heloisa Jahn. São Paulo: Iluminuras, 2002.

PIGLIA, Ricardo. Respiração artificial. Trad. Heloisa Jahn. São Paulo: Companhia das Letras, 2009.

PIGLIA, Ricardo. Alvo noturno. Trad. Heloisa Jahn. São Paulo: Companhia das Letras, 2011.

PIGLIA, Ricardo. Ficción y política en la literatura argentina. In: . Crítica y ficción. Buenos Aires: Debolsillo, 2014a, pp. 114-120.

PIGLIA, Ricardo. Notas en un diário. In: . Antología personal. Buenos Aires: Fondo de Cultura Economica, 2014b, pp. 253-263.

PIGLIA, Ricardo. Novela y utopia (1985). In: . Crítica y ficción. Buenos Aires: Debolsillo, 2014c, pp. 82-96.

PIGLIA, Ricardo. Plata quemada. Buenos Aires: Debolsillo, 2014d.

PIGLIA, Ricardo. Los diarios de Emilio Renzi - Años de formación. Barcelona: Editorial Anagrama, 2015a.

PIGLIA, Ricardo. Os livros de minha vida. Páginas de uma autobiografia futura. In: Revista Peixe-Elétrico, v. 1, no 1, 2015b. 
PIGLIA, Ricardo. Los diarios de Emilio Renzi - Los años felices. Barcelona: Editorial Anagrama, 2016.

PIGLIA, Ricardo. Notas sobre Macedonio en un diário. Clarín, Cultura y Nación, no 12, dez. 1985 .

POE, Edgar Alan. The Narrative of Arthur Gordon Pym of Nantucket 1837. In: Edgar Alan Poe: Sixty-Seven Tales. The Narrative of Artur Gordon Pym of Nantucket. The Raven and other Poems. New York: Gramercy Books, 1990.

SCHWARZ, Adriano. A tendência autobiográfica do romance contemporâneo: Coetzee, Roth e Piglia. Novos Estudos - CEBRAP, São Paulo, no 95, mar. 2013, pp. 83-97.

TRILLING, Lionel. The Liberal Imagination: Essays on Literature and Society. New York: Viking Press, 1950.

TRILLING, Lionel. Georg Orwell and the Politics of Truth. In: The Opposing Self: Nine Essays in Criticism. New York: Viking Press, 1955.

TRILLING, Lionel. Sincerity and authenticity. Cambridge: Harvard University Press, 1973.

WALSER, Robert. Jakob von Gunten. Um diário. Trad. Sérgio Tellaroli. São Paulo: Companhia das Letras, 2011.

WHITE, Hayden. Introduction: Historical Fiction, Fictional History and Historical Reality. Rethinking History, v. 9, no 2-3, jun.-sept. 2005, pp. 147-157. 